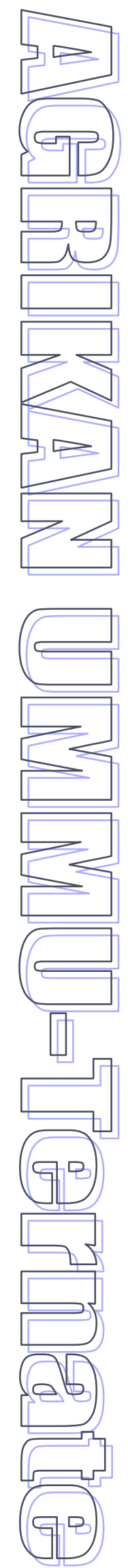

B juga mengikat antigen melalui reseptor pada permukaan selnya. Kebanyakan antigen menimbulkan respon sel dengan bantuan sel $\mathrm{T}$ (T-independent antigen). Beberapa antigen mampu mengaktifkan sel B untuk memproduksi Ig dengan bantuan sel $T$ (Kaufman, et.al., 2002).

Abbas and Lichtman (2000) menjelaskan mekanisme sel-sel imun dalam aksinya terhadap antigen tergantung pada beberapa faktor seperti tipe antigen, jumlah antigen yang masuk dan kondisi lingkungan seperti suhu dan populasi ikan. Secara in vitro, teknik tes antibodi menunjukkan kombinasi antibodi spesifik dengan anti gen. Dalam kompleks antigen-antibodi terbentuk reaksi precipitin dan algutinasi. Kompleks ini terbentuk melalui sistem dimana antigen dan antibodi bereaksi melalui kontak. Patogen terinkapasitasi dan dirusak melalui tahapan: (1) lisis, yaitu kombinasi antigen dan antibodi dengan komplemen yang selanjutnya merusak patogen terutama bakterium; (2) inaktivasi, dimana patogen tidak dapat berproduksi, selanjutnya menyebabkan kekurangannya populasi patogen; (3) inkapasitasi produk patogen, memblok produksi toksin, sehingga merusak patogen sendiri.

\section{SISTEM KEKEBALAN PADA UDANG}

\subsection{Sistem Kekebalan Seluler}

Pada udang sistem ini melibatkan beberapa tipe sel yang berbeda yaitu hemocyte dan phagosit (Lio-Po et al, 2001)

1. Hematocyte

Berdasarkan bentuk, morfologi dan pewarnaan, tipe-tipe hemocyte dapat dibedakan terutama pada darah krustase. Meskipun tipe-tipe ini tidak dapat disamakan seperti pada ikan dan vertebrata lain. Terdapat tiga jenis hemocyte yang dapat diisolasi dari hemolymph udang yaitu hyaline, semigranular dan granular. Hemocyte hyaline mempunyai kemampuan phagositosis. Ciri dari sel ini tidak mempunyai granular, ditemukan pada krustase dekapoda tetapi jumlah selnya relatif tergantung spesiesnya. Hemocyte semigranular mempunyai ciri sejumlah granular kecil pada sitoplasmanya seperti granulocyte pada vertebrata. Sel ini merespon adanya polisakarida dinding sel mikrobia termasuk lipopolisakarida bakteri (LPS) dan $\beta$ 1,3 glucan jamur. Sel tersebut mempunyai kemampuan untuk enkapsulasi benda-benda asing.

Hemocyte granular mempunyai ciri gelembung besar atau granular pada sitoplasmanya. Granular tersebut mempunyai peran dalam mereproduksi, menyimpan dan mensekresi senyawa antimikrobia. Namun tidak mempunyai aktifitas phagositosis dan kemampuan untuk enkapsulasi partikel asing terbatas. Peran utama hemocyte granular adalah menyimpan prophenol oxidase yang merupakan kunci dalam menyusun reaksi pertahanan udang. Sel ini dapat membongkar dan mengaktifkan prophenol oxidase oleh kehadiran $\beta$ 1,3 glucan, peptidoglycan dan LPS dari mikroorganisma. Aktifitas lain adalah sebagai katalis phenol oxidase pada oksidasi phenol untuk semiquinon dan quinon toksisitas mikroba untuk reaktifitasnya.

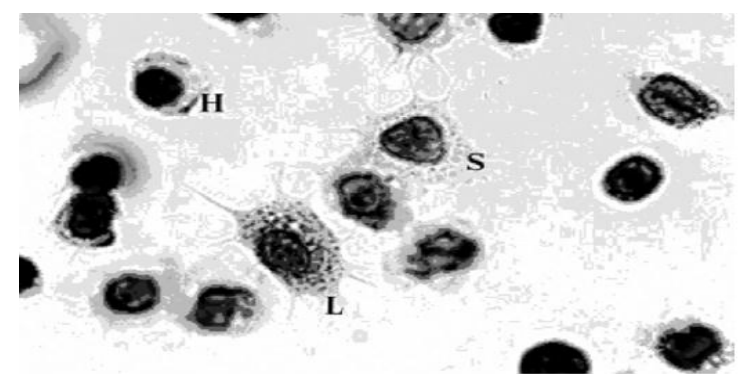

Gambar 3. Tipe-tipe sel hemocyte. $H=$ hyaline hemocyte, $s$ = semi-granular hemocyte, $\mathrm{L}=$ large granular hemocyte

\section{Fixed phagosit}

Fixed phagosit merupakan phagosit yang tidak bergerak dan menelan pathogen atau benda asing. Sel ini terdapat pada insang, hati dan jaringan lainnya (Gambar 4).

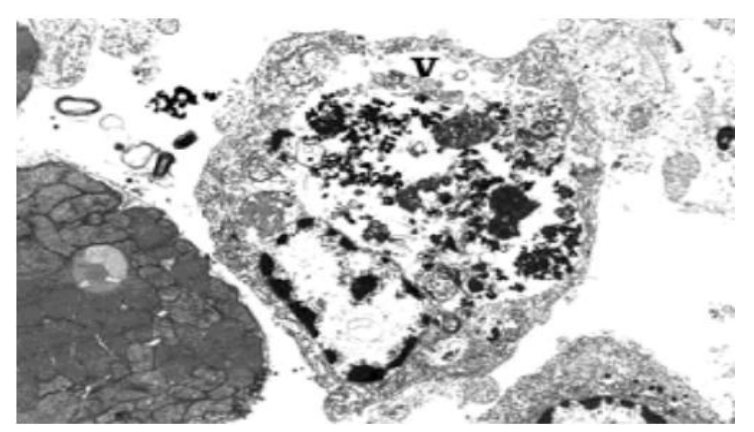

Gambar 4. Karakteristik fixed phagosit pada jaringan hati $P$ monodon dengan infeksi white spot virus $(\mathrm{V}=$ vakuola yang menelan dan mencerna virus). 
Sel ini berbeda dari sel darah dimana sel ini tidak bergerak dan tidak memiliki granula tetapi bertindak untuk membantu sel darah dalam mengeliminasi pathogen. Secara umum sel hemocyte dan phagosit menelan benda asing dan prosesnya diketahui sebagai phagositosis. Bentuk penggumpalan dan enkapsulasi pathogen atau benda asing oleh beberapa granula sel dan phagosit juga ditemukan dalam beberapa jaringan seperti insang, jaringan lymphoid dan hati.

3. Enzim Phenoloksidasi

Granula pada hemocyte granula mengandung isyarat/tanda untuk prophenoloxidase. Pada system aktifasi prophenoloxidase, granula melepaskan enzim dari hemocyte granula yang selanjutnya menyerang benda asing atau pathogen. Sistem ini juga bertindak untuk mendeteksi senyawa mikrobia seperti B-glucan, peptidoglycan and lipopolysakarida secara spesifik melalui binding proteins pada permukaan hemocyte. Proses prophenoloxidase 'bertingkat' merupakan respon dari produksi dan sekresi toksik secara metbolit (misalnya quinone, merupakan polymerase dari melanin) yang menghambat dan membunuh pathogen. Hasil akhir dari system ini membentuk bintik hitam, biasanya disekitar luka pada insang atau eksoskeleton

\section{Metabolit Intermediate}

Reactive oxygen intermediates (ROIs) diproduksi melalui respirasi dan aktifitas sel darah yaitu superoksida, hidrogen peroksida, hidrosil radikal dan oksigen. Metabolit ini dengan cepat mengeliminasi partikel pathogen dan terjadi peningkatan jumlah superoksida dan phagositosis mikroba atau benda asing yang masuk. Bagian dari protein dan metabolit intermediate seperti tersebut di atas yaitu clotting protein pada sel darah yang merespon terjadinya clotting dari hemolymph. Hal ini tidak hanya mencegah kekurangan hemolymph tetapi juga menghalangi masuknya pathogen ke dalam tubuh udang. Patogen terperangkap oleh gumpalan yang mengeliminasi melalui mekanisme lain.

\subsection{Sistem Kekebalan Humoral}

Sistem kekebalan humoral pada udang umumnya melibatkan faktor biologi yang berbeda pada hemolymph dan berfungsi menghambat atau mengeliminasi benda asing dan pathogen

1. Lectin

Lectin, atau agglutinin merupakan suatu protein yang mengikat karbohidrat dengan cepat dari beberapa tipe ikatan karbohidrat pada dinding sel pathogen atau benda asing dan reaksinya disebut aglutinasi. Selanjutnya aglutinasi menyebar pada tubuh saat eliminasi melalui satu atau lebih mekanisme. Fungsi aglutinin dalam sel darah adalah mengeluarkan beberapa komponen penting yang merangsang reaksi aglutinasi. Menurut Lio-Po et al (2001) sel darah atau lectin dalam darah krustase berbeda. Lectin adalah protein atau glikoprotein yang mempunyai kemampuan untuk mengenali dan mengikat karbohidrat pada permukaan bakteri atau jamur. Lectin tidak mempunyai aktifitas katalis atau enzimatik. Aksinya sederhana dengan menggerakkan atau menggumpalkan mikroorganisma dan secara tidak langsung terikat antara permukaan hemocyte dan mikroorganisma dan fungsinya adalah opsonin.

2. Senyawa Antimikroba

Produksi senyawa antimikrobia adalah aspek lain dari sistem kekebalan humoral dan mempunyai peran yang penting dalam kekebalan alami. Pada udang senyawa-senyawa yang ditemukan untuk efektifitas menghambat dan membunuh pathogen adalah bakterisidin dan peptid antimikroba lainnya. Bacterisidins adalah suatu klas dari senyawa yang ditemukan pada hemolymph dari beberapa udang dan spesies kepiting dan dengan cepat menghambat dan membasmi bakteri. Beberapa diantaranya bakteri gram (-) sementara yang lain membasmi bakteri gram (+) dan gram (-) termasuk juga parasit. .Bakterisidins juga ditemukan pada $P$ monodon dan efisien dalam menghambat proliferasi bacterial khususnya merangsang untuk membunuh sel bakteri (Supamattaya et al, 2000).

Peptid mikrobia juga membasmi pathogen dengan cepat. Peptid ini adalah protein dengan struktur molekul rendah dan menghambat dan membasmi patogen oleh penambahan $\mathrm{K}^{+}$yang masuk ke sel bakteri menyebabkan bakteri kehilangan kontrol metabolismenya. Beberapa peptid mempunyai 
struktur seperti dinding sel bakteri dan menghambat proliferasi sel. Penaieidins ditemukan pada $P$. vannamei yang berfungsi menghambat dan membasmi bakteri dan juga Fusarium oxysporum. Selanjutnya peptid ini digunakan sebagai antimikrobia alami untuk mengontrol penyakit bakterial.

Bagian dari system ini pada prinsipnya adalah tindakan melawan bakteri dan pathogen lain, penyelidikan senyawa antiviral dititik beratkan pada dampak penyakit viral pada udang $P$ japonicus yang dapat bertahan hidup dari serangan Penaeid acute Viremia (PAV) dimana plasmanya mengandung substansi yang mempunyai beberapa aksi sebagai faktor penetralisasi dan efektif membasmi virus. Hasil yang sama dilaporkan pada kasus Taura Syndrome Virus (TSV) pada $P$ vannamei. Selanjutnya hal ini sebagai kunci untuk mempelajari struktur dan karakteristik biokimia dari substansi tersebut sebagai pembatas pertumbuhan kultur sel krustase (Sritunyalucksana, 2001).

\subsection{Mekanisme Sistem kekebalan Alami Pada Udang}

Mekanisme sistem kekebalan udang terhadap serangan mikroorganisma (virus, bakteri dan jamur) dapat dilihat pada (Gambar 5).

Mikroorganisma yang masuk direspon oleh hemocyte dengan mengenalii dan mengikatnya. Sel ini merespon adanya polisakarida dinding sel mikrobia termasuk lipopolisakarida bakteri (LPS) dan $\beta$ 1,3 glucan jamur. Selain itu juga direspon oleh peptide antibakterial dengan mengikat bakteri yang masuk.

Pada permukaan sel hemocyte terdapat reseptor tempat mengikat LPS (lipopolysaccharida), $\beta$ 1,3 glucan dan PG (petidoglycan) dengan bantuan binding protein (BP). Kemudian hemocyte mengalami degranulasi dan melepaskan protein. Protein dapat berupa pro-enzymes (enzim transgluminase, prophenoloxidase activating enzim/ppA) dan yang lain berupa substansi (penaeidins dan lectins)

Protein-protein tersebut kemudian melakukan clotting dengan bantuan enzim transgluminase dan mengaktivasi sistem prophenoloxidase (proPO)

- Pada sistem proPO, enzim transgluminase berikatan dengan prophenoloxidase activating enzyme (ppA) dihambat oleh Proteinase inhibitor (pacifascin, 2 macroglobulin, Kazals dan Serpins) sehingga terbentuk ppA saja yang berperan dalam pembentukan $\mathrm{PO}$ dari pro $\mathrm{PO}$

- PO mengkatalis phenol menjadi quinon dengan bantuan oksigen sehingga terjadi melanisasi sehingga timbul bercak hitam pada kutikula

- Pada proses aktifasi seluler setelah degranulasi hemocyte terjadi pelekatan antara sel mikoorganisma, peroxinacin dan mas-like protein dan terjadi enkapsulasi (beberapa hemocyte bergabung untuk menandai benda-benda asing ) dan akhirnya terjadi phagositosis.

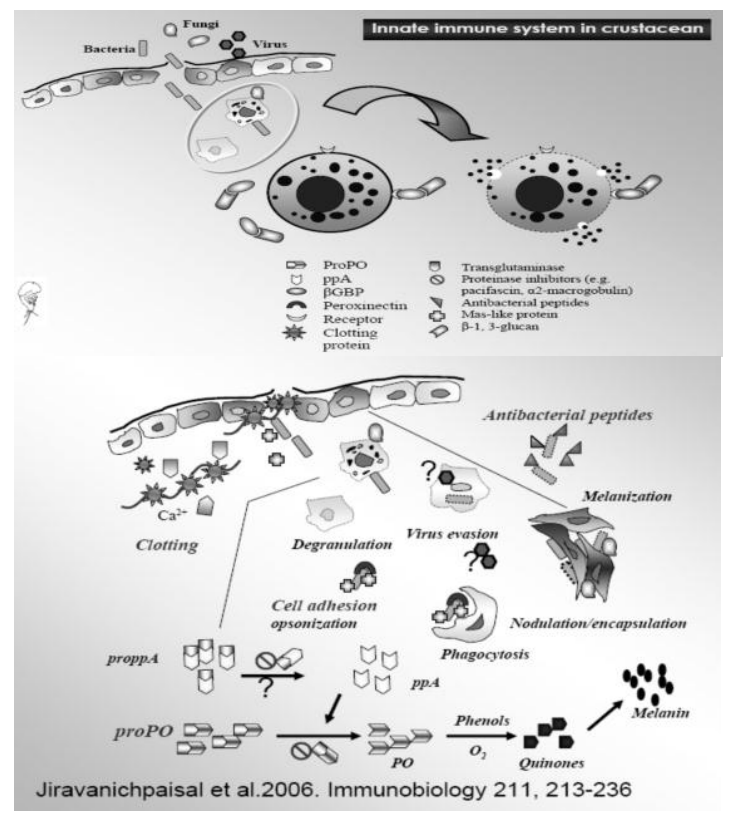

Gambar 5. Sistem pertahanan Crustacea yang diperantarai hemocyte.

\section{PENUTUP}

??????????????????????????????????????????????

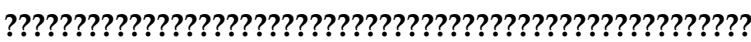

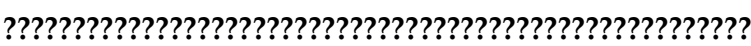

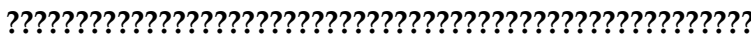

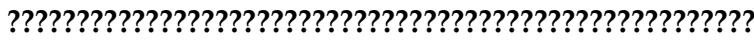

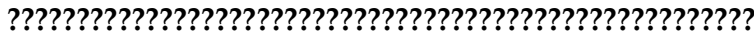
?????????????????????????????????????????????????? ??????????????????????????????????????????????????? ?????? 


\section{DAFTAR PUSTAKA}

Abbas, K.A, Lichtman, A.H. Pober, J.S,. 2000. Cellular and Molucular Immunology. W.b Saunders company. Toronto.

Anderson, DP., 1992. Immunostimulants, Adjuvants, And Vaccine Carriers In Fish : Applications to Aquaculture. Annual. Rev. of Fish Diseases Aumailley et al, 1993;

Ellis, A.E. 1999. Immunity To Bacteria In Fish. Journal of Fish and Shellfish Immunolgy

Galindo-Villegas, J. \& H. Hosokawa, 2004. Immunostimulants: Toward Temporary Prevention of Diseases in Marine Fish. Kochi University, Faculty of Agriculture. Laboratory of Fish Nutrition B200 Monobe, Nankoku, Kochi 783-8502 JAPAN.

http://id.wikipedia.org/wiki/immunity)

Irianto, A., 2005. Patologi ikan teleostei.Gaja mada University Press. Yogyakarta.

Kaufman, S.H.E, A. Sher, R. Ahmed. 2002. Immunology of Infection Disease. ASM Press, Washington, DC.

Lio-Po.G. D, C. R. Lavilla and E. R. Cruz-Lacierda. 2001. Health Manajement in Aquaculture. Aquacultur Departement. SEAFDEC. Tigbauan Iloilo. Phillippines.

Robertsen, Borre. 1999. Modulation Of The Non-Spesific Defence Of Fish By Structurally Conserved Microbial Polymers. Journal of Fish dan Shellfish Immunology. Academic Press.

Sritunyalucksana, K. 2001. Characterisation of Some Immune Genes in the Black Tiger Shrimp, Penaeus monodon. Acta Universitatis Upsaliensis. Comprehensive Summaries of Uppsala Dissertations from the Faculty of Science and Technology 645, 45 pp. Uppsala. ISBN 91554-5087-3

Subowo, Prof.dr.,MSc.,PhD. 1993. Imunobiologi. Penerbit Angkasa, Bandung.

Supamattaya. K. V. Chittiwani and M. Boonyaratpalin. 2000. Immunological factors in Black Tiger shrimp, Penaeus monodon, Fabricius. Songklanakarin J. Sci.Technol. 22(Suppl.):345-358 (in Thai).

Vadstein, O.1997.The use of immunostimulation in marine larviculture : possibilities and challenges. Aquaculture Elsevier. 


\title{
PEMBERIAN PAKAN FITOPLANKTON YANG BERBEDA TERHADAP KEPADATAN ROTIFER Brachionus plicatilis SKALA LABORATORIUM
}

\author{
Anita Padang*, La Rajaku** \& M. Sangadji** \\ *Staf Pengajar FPIK UNIDAR-Ambon, $e$-mail: - \\ **Alumni FPIK UNIDAR-Ambon, $e$-mail: -
}

\begin{abstract}
ABSTRAK
Rotifer merupakan kelompok zooplankton yang mempunyai peran penting sebagai pakan hidup bagi berbagai jenis ikan yang dibudidayakan. Dalam kegiatan budidaya, kultur rotifer merupakan kegiatan yang sangat penting, dimana dalam kegiatan tersebut dapat menggunakan pakan buatan maupun pakan alami fitoplankton. Tujuan dari penelitian adalah mengetahui jenis pakan fitoplankton yang tepat terhadap kepadatan rotifer Brachionus plicatilis. Penelitian yang dilaksanakan pada bulan Desember 2010 di Laboratorium Pakan Alami Balai Budidaya Laut Ambon dimana bibit rotifer Brachionus plicatilis ditebarkan ke dalam wadah kultur yang telah steril dengan kepadatan awal 10 ind/ml, kemudian diberi aerasi. Selama 14 hari pemeliharaan rotifer Brachionus plicatilis diberikan pakan alami fitoplankton jenis Chlorella sp, Cocolithophore $s p$ dan Tetraselmis sp. Kepadatan Brachionus plicatilis dengan pakan fitoplankton jenis Tetraselmis $s p$ dan Cocolithophore $s p$ mencapai puncak kepadatan tertinggi pada hari kedelapan sedangkan Chlorella sp lebih lambat yaitu pada hari keduabelas. Tetraselmis sp memberikan kepadatan tertinggi yaitu sebesar $247 \mathrm{ind} / \mathrm{ml}$, Cocolithophore sp sebesar $66 \mathrm{ind} / \mathrm{ml}$ dan Chlorella sp sebesar $147 \mathrm{ind} / \mathrm{ml}$.
\end{abstract}

Kata Kunci: Brachionus plicatilis, Chlorella sp, Cocolithophore sp, Tetraselmis sp

\section{PENDAHULUAN}

1.1. Latar Belakang

Rotifer merupakan kelompok zooplankton yang mempunyai peran penting sebagai pakan hidup bagi berbagai jenis ikan yang dibudidayakan. Dalam usaha budidaya ikan, rotifer sangat diperlukan sebagai pakan awal larva hingga mencapai benih karena ukurannya sesuai dengan bukaan mulut larva, teknologi produksi massalnya sudah dikuasai dan terus dikembangkan (Sorgeloos, 1992). Rotifer juga memiliki kecepatan renang rendah, hidup melayang dalam air sehingga mudah ditangkap oleh larva (Waynarovich \& Horvath 1980).

Ketersediaan pakan rotifer erat kaitannya dengan keberhasilan suatu unit pembenihan. Watanabe (1993) menyatakan bahwa rotifer merupakan pakan alami yang paling cocok bagi larva ikan laut yang baru menetas karena kebutuhan akan protein sebesar $40-60 \%$ dan lemak sebesar $13-16 \%$ dapat dipenuhi. Sedangkan Ghufran (2007) mengemukakan bahwa rotifer merupakan pakan yang baik untuk larva ikan kerapu macan (Epinephelus fuscoguttatus).

Selanjutnya rotifer juga memerlukan pakan bagi pertumbuhannya, dimana hingga saat ini rotifer masih mengandalkan pakan hidup berupa fitoplankton sebagai makanannya. Sedangkan pakan buatan komersil sebetulnya sudah tersedia, namun penggunaan pakan ini memerlukan peralatan dan teknologi tinggi.

Dalam kegiatan budidaya, kultur rotifer Brachionus plicatilis merupakan kegiatan yang sangat penting, dimana dalam kegiatan tersebut dapat menggunakan pakan buatan maupun 